\title{
Short communication: Variation in feed efficiency hampers use of carbon dioxide as a tracer gas in measuring methane emissions in on-farm conditions
}

\author{
P. Huhtanen, ${ }^{1 *} \odot$ A. R. Bayat, ${ }^{2} \oplus$ P. Lund, ${ }^{3} \odot$ A. L. F. Hellwing, ${ }^{3}{ }^{\oplus}$ and M. R. Weisbjerg ${ }^{3} \odot$ \\ ${ }^{1}$ Department of Agricultural Research for Northern Sweden, Swedish University of Agricultural Sciences, SE-901 83 Umeå, Sweden \\ ${ }^{2}$ Production Systems, Natural Resources Institute Finland (LUKE), 31600 Jokioinen, Finland \\ ${ }^{3}$ Department of Animal Science, Aarhus University, AU Foulum, PO Box 50, 8830 Tjele, Denmark
}

\begin{abstract}
Breeding cows for low $\mathrm{CH}_{4}$ emissions requires that the trait is variable and that it can be recorded with low cost from an adequate number of individuals and with high precision, but not necessarily with high accuracy if the trait is measured with high repeatability. The $\mathrm{CH}_{4}: \mathrm{CO}_{2}$ ratio in expired breath is a trait often used as a tracer with the production of $\mathrm{CO}_{2}$ predicted from body weight (BW), energy-corrected milk yield, and days of pregnancy. This approach assumes that efficiency of energy utilization for maintenance and production is constant. Data (307 cow-period observations) from 2 locations using the same setup for measuring $\mathrm{CH}_{4}$ and $\mathrm{CO}_{2}$ in respiration chambers were compiled, and observed production of $\mathrm{CH}_{4}$ and $\mathrm{CO}_{2}$ was compared with the equivalent predicted production using 2 different approaches. Carbon dioxide production was predicted using a previously reported model based on metabolic BW and energy-corrected milk production and a currently developed model based on energy requirements and the relationship between observed $\mathrm{CO}_{2}$ and heat production (models 1 and 2, respectively). Animals used were categorized (low, medium, and high efficiency) according to (1) residual feed intake and (2) residual milk production. Model 1 underestimated $\mathrm{CH}_{4}$ production by $15 \%$, whereas model 2 overestimated $\mathrm{CH}_{4}$ by $1.4 \%$ for the whole database. Model 1 underestimated $\mathrm{CO}_{2}$ production by 2.8 and $0.9 \mathrm{~kg} / \mathrm{d}$ for low- and high-efficiency cows, respectively, whereas model 2 underestimated $\mathrm{CO}_{2}$ production by $0.9 \mathrm{~kg} / \mathrm{d}$ for low-efficient animals but overestimated it by $1.2 \mathrm{~kg} / \mathrm{d}$ for high-efficiency cows. Efficient cows produce less heat, and consequently $\mathrm{CO}_{2}$, per unit of metabolic body weight and energy-corrected milk than
\end{abstract}

Received March 19, 2020.

Accepted May 13, 2020.

*Corresponding author: pekka.huhtanen@slu.se inefficient cows, challenging the use of $\mathrm{CO}_{2}$ as a tracer gas. Because of biased estimates of $\mathrm{CO}_{2}$ production, the models overestimated $\mathrm{CH}_{4}$ production of high-efficiency cows by, on average, $17 \%$ relative to low-efficiency cows, respectively. Selecting low $\mathrm{CH}_{4}$-emitting cows using a $\mathrm{CO}_{2}$ tracer method can therefore favor inefficient cows over efficient cows.

Key words: methane, $\mathrm{CO}_{2}$ tracer method, breeding, dairy cow

\section{Short Communication}

Methane $\left(\mathrm{CH}_{4}\right)$ is a greenhouse gas with a global warming potential 28 times that of $\mathrm{CO}_{2}$ (Myhre et al., 2013). Enteric $\mathrm{CH}_{4}$ from livestock accounts for $17 \%$ of global $\mathrm{CH}_{4}$ emissions and $3.3 \%$ of total global greenhouse gas emissions from human activities (Knapp et al., 2014). Therefore, there is significant research interest in finding strategies to mitigate enteric $\mathrm{CH}_{4}$ emissions. The focus has been on dietary manipulation and different feed additives. Animal breeding that exploits natural animal variation in $\mathrm{CH}_{4}$ emissions is suggested as a mitigation strategy that is inexpensive, permanent, and cumulative (Hayes et al., 2013). It has been shown that $\mathrm{CH}_{4}$ emission is under some genetic control from the host animal (Lassen and Løvendahl, 2016), but it is controlled much more by other factors in the surrounding environment, especially feed intake and diet composition.

A successful program for selecting cows for low $\mathrm{CH}_{4}$ emissions requires that the selection trait be variable and that the trait be easily and precisely recordable at low cost on an adequate number of animals. Several methods, often referred to as "sniffer methods," have been developed to measure $\mathrm{CH}_{4}$ concentration in the breath of cows during milking or feeding. The methods are based on measuring $\mathrm{CH}_{4}$ concentration (Garnsworthy et al., 2012) or $\mathrm{CH}_{4}: \mathrm{CO}_{2}$ ratio (Madsen et al., 2010). The gas ratio method developed by Madsen et al. (2010) is based on predicted $\mathrm{CO}_{2}$ production as a 
tracer gas for $\mathrm{CH}_{4}$ production as $\mathrm{CH}_{4}=\mathrm{CH}_{4}: \mathrm{CO}_{2} \times$ predicted $\mathrm{CO}_{2}$ production. Production of $\mathrm{CO}_{2}$ is predicted from metabolic BW (MBW), ECM yield, and days of pregnancy. This approach assumes that efficiency of energy utilization for maintenance and production is constant. However, both fasting heat production per kilogram of MBW (Yan et al., 1997) and milk energy output (and heat loss) at zero energy balance at a given ME intake (Kebreab et al., 2003) vary markedly. In addition, body energy retention or mobilization will affect $\mathrm{CO}_{2}$ production. Between-cow variation in feed efficiency and energy balance can therefore result in biased estimates of $\mathrm{CO}_{2}$ production and consequently affect ranking of the cows on the basis of $\mathrm{CH}_{4}$ production as discussed earlier by Huhtanen et al. (2015). Lassen and Løvendahl (2016) also discussed that the Madsen et al. (2010) method ignores whatever animal variation there might be in $\mathrm{CO}_{2}$ production. The objective of the present study was to examine how differences in feed efficiency expressed as residual feed intake (RFI) or residual ECM yield (RECM) influence $\mathrm{CH}_{4}$ production estimated from $\mathrm{CH}_{4}: \mathrm{CO}_{2}$ ratio and predicted $\mathrm{CO}_{2}$ production using data obtained from respiration chamber studies.

The data set consisted of $307 \mathrm{cow} /$ period observations from 11 studies (32 diets) from respiration chamber studies conducted at the Danish Cattle Research Centre (DCRC; Foulum, Denmark; 171 cow-periods) and Natural Resources Institute Finland (LUKE; Jokioinen, Finland; 136 cow-periods). Details of respiration chambers are described by Hellwing et al. (2012). Details of the animals, diets, and designs are described in the original publications (Supplemental File S1; https:// doi.org/10.3168/jds.2020-18559). A summary of animal and feed data used in this study is presented in Table 1.
Production of $\mathrm{CO}_{2}$ was predicted using the method described by Madsen et al. (2010) (model 1):

$$
\begin{aligned}
\mathrm{CO}_{2}(\mathrm{~kg} / \mathrm{d})= & 180 \times(5.6 \times \mathrm{MBW}+22 \times \mathrm{ECM}) \\
& \times 44 / 22.4 \times 0.001
\end{aligned}
$$

where $180=$ liters of $\mathrm{CO}_{2}$ per heat production unit (HPU), ECM is in kilograms per day, MBW is in kilograms, 44 is the molecular weight of $\mathrm{CO}_{2}, 22.4$ is liters of $\mathrm{CO}_{2}$ per mole, and 0.001 converts grams to kilograms.

Production of $\mathrm{CO}_{2}$ was also estimated indirectly from $\mathrm{ME}$ requirements, assuming $0.6 \mathrm{MJ} / \mathrm{kg}$ of $\mathrm{MBW}$ for maintenance (Yan et al., 1997) and that production of $1 \mathrm{~kg}$ of ECM produces 1.9 MJ of heat (ECM = $3.14 \mathrm{MJ} / \mathrm{kg}$ and efficiency of ME utilization for milk production $=0.62$ ). Heat production was transformed to $\mathrm{CO}_{2}$ production using the coefficient $(101.2 \mathrm{~g} / \mathrm{MJ})$ estimated from the current data [coefficient of determination $\left(\mathbf{R}^{2}\right)=0.97$; root mean squared error (RMSE) $3.1 \%$ of observed mean] (model 2):

$$
\begin{gathered}
\mathrm{CO}_{2}(\mathrm{~kg} / \mathrm{d})=101.2 \\
\times(0.6 \times \mathrm{MBW}+1.9 \times \mathrm{ECM}) / 1,000 .
\end{gathered}
$$

Changes in BW or energy balance were not considered because these often cannot be measured reliably on practical farms. Residual feed intake was calculated as the difference between predicted and observed DMI, and RECM as the difference of predicted and observed ECM yield. The parameters for RFI and RECM models were estimated from the current data. Negative RFI values indicate high efficiency [cows eat less than predicted at the same ECM, MBW, and retained energy

Table 1. Summary statistics of animal and feed data used in this study

\begin{tabular}{lcccc}
\hline Item & Mean & SD & Minimum & Maximum \\
\hline DMI, kg/d & 20.2 & 4.50 & 10.1 & 30.9 \\
Proportion of forage & 0.58 & 0.141 & 0.36 & 0.99 \\
DIM & 184 & 103.9 & 11 & 757 \\
Milk, kg/d & 29.0 & 10.1 & 8.2 & 51.4 \\
ECM, kg/d & 30.3 & 9.41 & 8.2 & 52.0 \\
Milk fat, g/kg & 44.7 & 9.06 & 24.7 & 88.5 \\
Milk protein, g/kg & 36.1 & 4.28 & 28.6 & 53.9 \\
BW, kg & 614 & 95.5 & 404 & 847 \\
Digestibility, g/kg & & & & \\
OM & 725 & 35.2 & 640 & 798 \\
CP & 674 & 40.9 & 490 & 766 \\
NDF & 619 & 82.1 & 392 & 808 \\
Diet composition, g/kg of DM & & & & \\
Ash & 75 & 15.4 & 51 & 146 \\
CP & 170 & 19.8 & 124 & 233 \\
NDF & 351 & 49.6 & 224 & 486 \\
\hline
\end{tabular}


(RE)], whereas for RECM positive values indicate high efficiency (cows produce more than expected at the same DMI, MBW, and RE. The MIXED procedure (SAS Institute Inc., Cary, NC) was used to predict DMI and ECM:

$$
\begin{gathered}
\text { Predicted DMI }=\mathrm{b}_{0}+\mathrm{b}_{1} \times \mathrm{ECM} \\
+\mathrm{b}_{2} \times \mathrm{MBW}+\mathrm{b}_{3} \times \mathrm{RE}_{\mathrm{p}}+\mathrm{b}_{4} \times \mathrm{RE}_{\mathrm{n}}+\operatorname{Exp} \\
+\operatorname{Diet}(\operatorname{Exp})+\operatorname{Period}(\operatorname{Exp})
\end{gathered}
$$

where $b_{0}$ is the intercept, $b_{1}$ is the partial regression coefficient of DMI on ECM yield $(\mathrm{kg} / \mathrm{d}), \mathrm{b}_{2}$ is the partial regression coefficient of intake on MBW $(\mathrm{kg}), \mathrm{b}_{3}$ is the partial regression coefficient of intake on positive energy balance $\left(\mathbf{R E}_{\mathrm{p}}, \mathrm{MJ} / \mathrm{d}\right), \mathrm{b}_{4}$ is the partial regression coefficient of intake on negative energy balance $\left(\mathbf{R E}_{n}\right.$, $\mathrm{MJ} / \mathrm{d}$ ), and Exp, Diet(Exp), and Period(Exp) are random effects of experiment, diet within experiment, and period within experiment, respectively.

$$
\begin{gathered}
\text { Predicted ECM }=\mathrm{b}_{0}+\mathrm{b}_{1} \times \mathrm{GE} \text { intake } \\
+\mathrm{b}_{2} \times \mathrm{MBW}+\mathrm{b}_{3} \times \mathrm{RE}_{\mathrm{p}}+\mathrm{b}_{4} \times \mathrm{RE}_{\mathrm{n}}+\operatorname{Exp} \\
+\operatorname{Diet}(\operatorname{Exp})+\operatorname{Period}(\operatorname{Exp}),
\end{gathered}
$$

where $b_{1}$ is the partial regression coefficient of gross energy (GE) intake (MJ/d) and the other factors are as described in equation [1].

The cows were categorized into 3 efficiency groups of equal size ( $\mathrm{n}=102-103)$ on the basis of RFI (low, medium, and high RFI) and on the basis of RECM (low, medium, and high RECM). Differences between the efficiency classes were tested with MIXED model analysis with efficiency class as a fixed factor and Exp, Diet(Exp), and Period(Exp) as random factors.
Overall variability of $\mathrm{CH}_{4}$ production was large [coefficient of variation $(\mathbf{C V})=23.2 \%$ ] reflecting variation in DMI and diet composition (Table 2). The variability was greater than that $(17 \%)$ reported by Yan et al. (2010), probably because the current data set included fat supplementation studies and slightly greater variability in DMI. When the effects of Exp, Diet(Exp), and Period(Exp) were taken into account in variance component analysis, the between-cow $\mathrm{CV}$ decreased to $11.7 \%$. Most of this variation was due to differences in DMI, as indicated by a much smaller $(5.7 \%) \mathrm{CV}$ in $\mathrm{CH}_{4}$ yield ( $\mathrm{g}$ of $\mathrm{CH}_{4} / \mathrm{kg}$ of DMI). Between-cow variability was even less for the $\mathrm{CH}_{4}: \mathrm{CO}_{2}$ ratio $(4.9 \%)$. Because of the small between-cow variability with the gold standard method, high precision of on-farm methods is required for correct ranking of cows based on $\mathrm{CH}_{4}$ emissions. In previous studies (breath sampling "sniffer" methods based on either $\mathrm{CH}_{4}$ concentration or $\mathrm{CH}_{4}$ : $\mathrm{CO}_{2}$ ratio), between-cow variability in these variables was much greater (Garnsworthy et al., 2012; Lassen et al., 2012; Bell et al., 2014; Negussie et al., 2017; van Engelen et al., 2018). In the study of Bell et al. (2014), between-cow $\mathrm{CV}$ in $\mathrm{CH}_{4}$ concentration varied between 22 and $67 \%$ on different farms. Much greater betweencow variability with sniffer methods indicates a large contribution of random measurement errors in observed values. Some reported gas ratios have been outside of the expected biological range; for example, values of 0.17 on a volume basis ( $62 \mathrm{~g} / \mathrm{kg}$ on weight basis) in the studies of Negussie et al. (2017) and van Engelen et al. (2018).

The model of Madsen et al. (2010) (model 1) clearly

\begin{tabular}{|c|c|c|c|c|c|}
\hline Item & Mean & SD & $\begin{array}{c}\text { Between-cow } \\
\text { CV, \% }\end{array}$ & Minimum & Maximum \\
\hline Observed $\mathrm{CH}_{4}, \mathrm{~g} / \mathrm{d}$ & 414 & 96.0 & 11.7 & 208 & 628 \\
\hline Observed $\mathrm{CO}_{2}, \mathrm{~kg} / \mathrm{d}$ & 13.5 & 2.43 & 11.2 & 7.4 & 18.6 \\
\hline Predicted $\mathrm{CO}_{2},{ }^{1} \mathrm{~kg} / \mathrm{d}$ & 11.5 & 2.27 & 10.9 & 6.5 & 16.7 \\
\hline Predicted $\mathrm{CO}_{2},{ }^{2} \mathrm{~kg} / \mathrm{d}$ & 13.7 & 2.58 & 10.3 & 7.9 & 19.5 \\
\hline $\mathrm{CH}_{4}, \mathrm{~g} / \mathrm{kg}$ of ECM & 14.4 & 3.53 & 11.0 & 7.5 & 31.6 \\
\hline $\mathrm{RFI},{ }^{3} \mathrm{~kg} / \mathrm{d}$ & 0.13 & 1.528 & 0.55 & -4.35 & 4.85 \\
\hline $\mathrm{RECM}^{\mathrm{A}} \mathrm{kg} / \mathrm{d}$ & -0.13 & 3.449 & 1.40 & -9.54 & 9.62 \\
\hline
\end{tabular}
underestimated $\mathrm{CO}_{2}$ production by approximately $15 \%$, whereas the model based on heat production (model 2), using the current energy requirements for maintenance and ECM production, estimated $\mathrm{CO}_{2}$ production ac-

Table 2. Summary statistics of gas production data

\footnotetext{
${ }^{1}$ Predicted using the equation of Madsen et al. (2010) (model 1).

${ }^{2}$ Predicted using heat production estimated from maintenance + heat increment from ECM production (model 2).

${ }^{3} \mathrm{RFI}=$ residual feed intake.

${ }^{4} \mathrm{RECM}=$ residual ECM yield.
} 
curately, as indicated by a small mean bias $(<2 \%$ of observed mean). The following relationships between observed and predicted $\mathrm{CO}_{2}\left(\mathbf{p C O}_{2}\right)$ production were estimated:

$$
\begin{gathered}
\text { Model 1: } \mathrm{CO}_{2} \text { production }(\mathrm{kg} / \mathrm{d})=2.46 \pm 0.36 \\
+0.95 \pm 0.030 \times \mathrm{pCO}_{2}\left(\mathrm{R}^{2}=0.773, \mathrm{RMSE}=1.16\right)
\end{gathered}
$$

Model 2: $\mathrm{CO}_{2}$ production $(\mathrm{kg} / \mathrm{d})=1.91 \pm 0.37$

$$
+0.84 \pm 0.026 \times \mathrm{pCO}_{2}\left(\mathrm{R}^{2}=0.780, \mathrm{RMSE}=1.14\right) .
$$

The lack of correlation from unity indicates that there is considerable variation between animals in the efficiency of nutrient utilization for both maintenance and production.

Both models predicted $\mathrm{CH}_{4}$ emissions precisely $\left(\mathrm{R}^{2}\right.$ $=0.86$; RMSE $8.6-8.8 \%$ of observed mean). Model 1 (Madsen et al., 2010) underestimated $\mathrm{CH}_{4}$ production by $15 \%$, whereas the model based on feeding recommendation was accurate (overpredicted $\mathrm{CH}_{4}$ by $1.4 \%$ ). A close relationship between observed and predicted values is not surprising because the $\mathrm{CH}_{4}: \mathrm{CO}_{2}$ ratio used was measured in respiration chambers. In on-farm conditions, precision is likely less because $\mathrm{CH}_{4}: \mathrm{CO}_{2}$ ratios measured by the sniffer were not strongly correlated with gas ratios measured by GreenFeed (Huhtanen et al., 2015) or respiration chambers (Difford et al., 2018). In the current study, predicted $\mathrm{CO}_{2}$ production predicted $\mathrm{CH}_{4}$ emissions better than the gas ratio $\left(\mathrm{R}^{2}=0.60\right.$ for both $\mathrm{CO}_{2}$ models vs. 0.40) despite relatively large between-Diet(Exp) variation in the gas ratio $(\mathrm{CV}=$ $7.7 \%$ ), probably arising from fat supplementation that reduces $\mathrm{CH}_{4}$ production (Grainger and Beauchemin, 2011). In the study of Difford et al. (2018), predicted $\mathrm{CO}_{2}$ production explained variation in observed $\mathrm{CH}_{4}$ production measured in respiration chambers as well as $\mathrm{CH}_{4}$ production predicted from $\mathrm{CH}_{4}: \mathrm{CO}_{2}$ using $\mathrm{CO}_{2}$ as a tracer gas $(\mathrm{r}=0.74$ vs. 0.77$)$; that is, measurements of $\mathrm{CH}_{4}: \mathrm{CO}_{2}$ did not improve precision $\mathrm{CH}_{4}$ prediction.

The high-efficiency cows, categorized based on RECM, produced $6.6 \mathrm{~kg} / \mathrm{d}(P<0.001)$ more ECM than the low-efficiency cows at the same DMI, BW, and RE (Table 3$)$. The high-efficiency cows produced $25(P=$ $0.02)$ and $21 \mathrm{~g} / \mathrm{d}(P=0.03)$ less $\mathrm{CH}_{4}$ than the low- and the medium-efficiency cows, respectively, but the reverse was true for predicted $\mathrm{CH}_{4}$ production, which was 40 and $42 \mathrm{~g} / \mathrm{d}$ greater $(P<0.001)$ for the high- than the low-efficiency cows when estimated using model 1 and model 2. The difference between observed and predicted $\mathrm{CH}_{4}$ production (model 2) was $62 \mathrm{~g} / \mathrm{d}(P<$ $0.001)$, ranging from underprediction of $26 \mathrm{~g} / \mathrm{d}(6.7 \%)$ for the low-efficiency cows to overprediction of $36 \mathrm{~g} / \mathrm{d}$
$(9.9 \%)$ for high-efficiency cows. With model 1 , underprediction of $\mathrm{CH}_{4}$ production decreased $(P<0.001)$ from $83 \mathrm{~g} / \mathrm{d}$ in the low-efficiency cows to $27 \mathrm{~g} / \mathrm{d}$ in the high-efficiency cows. Because the differences between the efficiency groups in the $\mathrm{CH}_{4}: \mathrm{CO}_{2}$ ratio were small, the biases in predicted $\mathrm{CH}_{4}$ production were due to errors in predicting $\mathrm{CO}_{2}$ production. In the low-efficiency cows, observed $\mathrm{CO}_{2}$ production was, on average, 0.9 $\mathrm{kg} / \mathrm{d}$ more than the predicted value, whereas for the high-efficiency cows, it was $1.2 \mathrm{~kg} / \mathrm{d}$ less than predicted (model 2). Differences between low- and high-efficiency cows in predicted $\mathrm{CO}_{2}$ production were similar (2.1 $\mathrm{kg} / \mathrm{d}$ ) when estimated by model 1 or by model 2 . Efficient cows produce less heat, and consequently less $\mathrm{CO}_{2}$, per unit of MBW and ECM than inefficient cows, violating the hypothesis of using $\mathrm{CO}_{2}$ as a tracer gas. Based on regression analysis, $1 \mathrm{~g}$ of bias in predicted $\mathrm{CH}_{4}$ production was associated with $0.065 \pm 0.0028(P$ $<0.001) \mathrm{kg} / \mathrm{d}$ difference in ECM yield. Our findings are consistent with Huhtanen et al. (2015), who discussed the possible problems of using $\mathrm{CO}_{2}$ as a tracer gas in quantification of $\mathrm{CH}_{4}$ production.

Residuals (observed - predicted) of both $\mathrm{CO}_{2}(16.0$ $\mathrm{g} / \mathrm{MJ})$ and $\mathrm{CH}_{4}$ production $(0.52 \mathrm{~g} / \mathrm{MJ})$ increased $(P$ $<0.001$ ) with observed energy balance. When cows are in positive energy balance, true $\mathrm{CO}_{2}$ production is greater than $\mathrm{CO}_{2}$ production predicted from MBW and ECM yield, resulting in underestimation of $\mathrm{CH}_{4}$ production. In contrast, when cows are in negative energy balance, $\mathrm{CH}_{4}$ production is overestimated, because milk production promoted by the mobilization of body tissues increases predicted $\mathrm{CO}_{2}$ production but does not result in a concurrent production of $\mathrm{CH}_{4}$. However, under on-farm conditions, accurate estimates of energy balance are difficult. In addition to random errors in measuring BW change, the poor relationship between BW change and actual energy balance may impede improvements in predictions of $\mathrm{CO}_{2}$ production. The difference between the low- and high-RECM groups in $\mathrm{CH}_{4}$ intensity $\left(\mathrm{CH}_{4} / \mathrm{ECM}, \mathrm{g} / \mathrm{kg}\right)$ was 4.3 and $2.3 \mathrm{~g} /$ $\mathrm{kg}$ when calculated using observed and predicted $\mathrm{CH}_{4}$, respectively.

Average DMI differed $(P<0.001)$ among the high, medium-, and low-efficiency cows when categorized according to RFI, with no differences $(P>0.11)$ in ECM, BW, or energy balance (Table 4). Predicted $\mathrm{CH}_{4}$ production was similar among the efficiency groups, because $\mathrm{CH}_{4}: \mathrm{CO}_{2}$ and factors influencing predicted $\mathrm{CO}_{2}$ production (ECM yield, MBW) did not differ between the groups. In contrast, observed $\mathrm{CH}_{4}$ production decreased $(P<0.001)$ with improved efficiency (reduced RFI) due to decreased DMI. Because of the biases in predicted $\mathrm{CO}_{2}$ production, $\mathrm{CH}_{4}$ production was over- 
Table 3. Milk and gas production characteristics of low-, medium- and high-efficiency cows ranked according to residual ECM production (RECM)

\begin{tabular}{|c|c|c|c|c|c|}
\hline \multirow[b]{2}{*}{ Item } & \multicolumn{3}{|c|}{ RECM } & \multirow[b]{2}{*}{ SEM } & \multirow[b]{2}{*}{$P$-value } \\
\hline & Low & Medium & High & & \\
\hline RECM, kg/d & -3.2 & 0.1 & 3.3 & 0.25 & $<0.001$ \\
\hline ECM, g/d & 23.2 & 26.7 & 29.8 & 2.12 & $<0.001$ \\
\hline DMI, $\mathrm{kg} / \mathrm{d}$ & 18.5 & 18.8 & 18.4 & 1.01 & 0.57 \\
\hline $\mathrm{BW}, \mathrm{kg}$ & 592 & 595 & 583 & 20.4 & 0.60 \\
\hline Retained energy, $\mathrm{MJ} / \mathrm{d}$ & 7.8 & 8.7 & 5.2 & 3.58 & 0.47 \\
\hline Observed $\mathrm{CH}_{4}, \mathrm{~g} / \mathrm{d}$ & 388 & 384 & 363 & 22.5 & 0.05 \\
\hline Predicted $\mathrm{CH}_{4}, \mathrm{~g} / \mathrm{d}$ & 301 & 325 & 341 & 19.6 & $<0.001$ \\
\hline Predicted $\mathrm{CH}_{4}, \mathrm{~g} / \mathrm{d}$ & 360 & 387 & 402 & 22.7 & $<0.001$ \\
\hline Observed - predicted $\mathrm{CH}_{4},{ }^{1} \mathrm{~g} / \mathrm{d}$ & 83 & 57 & 27 & 5.6 & $<0.001$ \\
\hline Observed - predicted $\mathrm{CH}_{4},{ }^{2} \mathrm{~g} / \mathrm{d}$ & 26 & -3 & -36 & 5.7 & $<0.001$ \\
\hline $\mathrm{CH}_{4} / \mathrm{DMI}, \mathrm{g} / \mathrm{kg}$ & 21.0 & 20.5 & 20.0 & 0.05 & 0.04 \\
\hline $\mathrm{CH}_{4} / \mathrm{CO}_{2}, \mathrm{~g} / \mathrm{kg}$ & 29.8 & 30.2 & 30.3 & 0.76 & 0.45 \\
\hline Observed $\mathrm{CO}_{2}, \mathrm{~kg} / \mathrm{d}$ & 12.9 & 12.7 & 12.1 & 0.57 & 0.02 \\
\hline Predicted $\mathrm{CO}_{2},{ }^{1} \mathrm{~kg} / \mathrm{d}$ & 10.0 & 10.7 & 11.2 & 0.53 & $<0.001$ \\
\hline Predicted $\mathrm{CO}_{2},{ }^{2} \mathrm{~kg} / \mathrm{d}$ & 12.0 & 12.7 & 13.2 & 0.60 & $<0.001$ \\
\hline Observed - predicted $\mathrm{CO}_{2},{ }^{1} \mathrm{~kg} / \mathrm{d}$ & 2.8 & 1.9 & 0.9 & 0.17 & $<0.001$ \\
\hline Observed - predicted $\mathrm{CO}_{2},{ }^{2} \mathrm{~kg} / \mathrm{d}$ & 0.9 & -0.1 & -1.2 & 0.19 & $<0.001$ \\
\hline $\mathrm{CO}_{2} / \mathrm{DMI}, \mathrm{g} / \mathrm{kg}$ & 699 & 679 & 611 & 11.1 & $<0.001$ \\
\hline $\mathrm{CH}_{4} / \mathrm{ECM}, \mathrm{g} / \mathrm{kg}$ & 17.1 & 15.0 & 12.9 & 0.73 & $<0.001$ \\
\hline $\mathrm{CO}_{2} / \mathrm{ECM}, \mathrm{g} / \mathrm{kg}$ & 589 & 510 & 442 & 25.1 & $<0.001$ \\
\hline
\end{tabular}

${ }^{1}$ Predicted using the equation of Madsen et al. (2010) (model 1).

${ }^{2}$ Predicted using heat production estimated from maintenance + heat increment from ECM production (model 2).

estimated (30 g/d) for the high-efficiency (low-RFI) cows and underestimated $(28 \mathrm{~g} / \mathrm{d})$ for the low-efficiency (i.e., high-RFI) cows (model 2). When estimated using model 1 (Madsen et al., 2010), similar biases between low- and high-efficiency cows were observed between observed and predicted $\mathrm{CH}_{4}$ and $\mathrm{CO}_{2}$ productions.

In conclusion, the use of $\mathrm{CO}_{2}$ as a tracer gas combined with $\mathrm{CH}_{4}: \mathrm{CO}_{2}$ ratio depends upon the underlying

Table 4. Milk and gas production characteristics of low-, medium- and high-efficiency cows ranked according to residual feed intake $(\mathrm{RFI})$

\begin{tabular}{|c|c|c|c|c|c|}
\hline \multirow[b]{2}{*}{ Item } & \multicolumn{3}{|c|}{ RFI } & \multirow[b]{2}{*}{ SEM } & \multirow[b]{2}{*}{$P$-value } \\
\hline & Low & Medium & High & & \\
\hline $\mathrm{RFI}, \mathrm{kg} / \mathrm{d}$ & -1.4 & 0.1 & 1.5 & 0.11 & $<0.001$ \\
\hline ECM, g/d & 26.9 & 26.7 & 25.5 & 2.41 & 0.28 \\
\hline DMI, kg/d & 17.3 & 19.0 & 19.5 & 1.01 & $<0.001$ \\
\hline $\mathrm{BW}, \mathrm{kg}$ & 583 & 602 & 581 & 20.5 & 0.11 \\
\hline Retained energy, MJ/d & 7.7 & 8.9 & 4.2 & 3.34 & 0.28 \\
\hline Observed $\mathrm{CH}_{4}, \mathrm{~g} / \mathrm{d}$ & 350 & 384 & 407 & 21.3 & $<0.001$ \\
\hline Predicted $\mathrm{CH}_{4},{ }_{2} \mathrm{~g} / \mathrm{d}$ & 321 & 323 & 315 & 21.3 & 0.58 \\
\hline Predicted $\mathrm{CH}_{4}, 2 \mathrm{~g} / \mathrm{d}$ & 383 & 386 & 374 & 24.4 & 0.43 \\
\hline Observed - predicted $\mathrm{CH}_{4},{ }_{2}^{1} \mathrm{~g} / \mathrm{d}$ & 30 & 58 & 87 & 5.2 & $<0.001$ \\
\hline Observed - predicted $\mathrm{CH}_{4},{ }^{2} \mathrm{~g} / \mathrm{d}$ & -30 & 3 & 28 & 6.4 & $<0.001$ \\
\hline $\mathrm{CH}_{4} / \mathrm{DMI}, \mathrm{g} / \mathrm{kg}$ & 20.7 & 20.2 & 20.9 & 0.66 & 0.06 \\
\hline $\mathrm{CH}_{4} / \mathrm{CO}_{2}, \mathrm{~g} / \mathrm{kg}$ & 30.2 & 29.9 & 30.2 & 0.76 & 0.63 \\
\hline Observed $\mathrm{CO}_{2}, \mathrm{~kg} / \mathrm{d}$ & 11.7 & 12.8 & 13.4 & 0.54 & 0.02 \\
\hline Predicted $\mathrm{CO}_{2},{ }^{1} \mathrm{~kg} / \mathrm{d}$ & 10.5 & 10.8 & 10.4 & 0.58 & $<0.001$ \\
\hline Predicted $\mathrm{CO}_{2},{ }^{2} \mathrm{~kg} / \mathrm{d}$ & 12.6 & 12.8 & 12.4 & 0.66 & $<0.001$ \\
\hline Observed - predicted $\mathrm{CO}_{2},{ }^{1} \mathrm{~kg} / \mathrm{d}$ & 1.0 & 2.0 & 2.9 & 0.17 & $<0.001$ \\
\hline Observed - predicted $\mathrm{CO}_{4},{ }^{2} \mathrm{~kg} / \mathrm{d}$ & -1.0 & -0.1 & 0.9 & 0.21 & $<0.001$ \\
\hline $\mathrm{CO}_{2} / \mathrm{DMI}, \mathrm{g} / \mathrm{kg}$ & 684 & 674 & 686 & 12.3 & 0.19 \\
\hline $\mathrm{CH}_{4} / \mathrm{ECM}, \mathrm{g} / \mathrm{kg}$ & 14.2 & 15.2 & 16.2 & 0.88 & $<0.001$ \\
\hline $\mathrm{CO}_{2} / \mathrm{ECM}, \mathrm{g} / \mathrm{kg}$ & 487 & 518 & 552 & 31.7 & $<0.001$ \\
\hline
\end{tabular}

${ }^{1}$ Predicted using the equation of Madsen et al. (2010) (model 1).

${ }^{2}$ Predicted using heat production estimated from maintenance + heat increment from ECM production (model 2). 
assumption that there is no variation in efficiency of energy utilization for maintenance or milk production among the cows. However, the results of the present study showed large differences in $\mathrm{CO}_{2}$ production between low- and high-efficiency cows at similar maintenance and milk production levels. Because of the biased estimates of $\mathrm{CO}_{2}$ production due to differences in the efficiency of nutrient utilization, this method favors inefficient cows over efficient cows in ranking of them according to their $\mathrm{CH}_{4}$ phenotypes. The method in its current form also favors selection of cows that partition nutrients to body energy retention rather than milk production.

\section{ACKNOWLEDGMENTS}

This project had no external funding. The authors have not stated any conflicts of interest.

\section{REFERENCES}

Bell, M. J., S. L. Potterton, J. Craigon, N. Saunders, R. H. Wilcox, M. Hunter, J. R. Goodman, and P. C. Garnsworthy. 2014. Variation in enteric methane emissions among cows on commercial dairy farms. Animal 8:1540-1546. https://doi.org/10.1017/ S1751731114001530.

Difford, G. F., D. W. Olijhoek, A. L. F. Hellwing, P. Lund, M. A. Bjerring, Y. de Haas, J. Lassen, and P. Løvendahl. 2018. Ranking cows' methane emissions under commercial conditions with sniffers versus respiration chambers. Acta Agric. Scand. A Anim. Sci. $68: 25-32$.

Garnsworthy, P. C., J. Craigon, J. H. Hernandez-Medrano, and N. Saunders. 2012. On-farm methane measurements during milking correlate with total methane production by individual dairy cows. J. Dairy Sci. 95:3166-3180. https://doi.org/10.3168/jds.2011-4605.

Grainger, C., and K. A. Beauchemin. 2011. Can enteric methane emissions from ruminants be lowered without lowering their production. Anim. Feed Sci. Technol. 166-167:308-320. https://doi.org/ 10.1016/j.anifeedsci.2011.04.021.

Hayes, B. J., H. A. Lewin, and M. E. Goddard. 2013. The future of livestock breeding: genomic selection for efficiency, reduced emissions intensity, and adaptation. Trends Genet. 29:206-214. https:/ /doi.org/10.1016/j.tig.2012.11.009.

Hellwing, A. L., P. Lund, M. R. Weisbjerg, M. Brask, and T. Hvelplund. 2012. Technical note: Test of a low-cost and animal-friendly system for measuring methane emissions from dairy cows. J. Dairy Sci. 95:6077-6085. https://doi.org/10.3168/jds.2012-5505.

Huhtanen, P., E. H. Cabezas-Garcia, S. Utsumi, and S. Zimmerman. 2015. Comparison of methods to determine methane emissions from dairy cows in farm conditions. J. Dairy Sci. 98:3394-3409. https://doi.org/10.3168/jds.2014-9118.
Kebreab, E., J. France, R. E. Agnew, T. Yan, M. S. Dhanoa, J. Dijkstra, D. E. Beever, and C. K. Reynolds. 2003. Alternatives to linear analysis of energy balance data from lactating dairy cows. J. Dairy Sci. 86:2904-2913. https://doi.org/10.3168/jds.S0022 -0302(03)73887-9.

Knapp, J. R., G. L. Laur, P. A. Vadas, W. P. Weiss, and J. M. Tricarico. 2014. Invited review: Enteric methane in dairy cattle production: Quantifying the opportunities and impact of reducing emissions. J. Dairy Sci. 97:3231-3261. https://doi.org/10.3168/jds .2013-7234.

Lassen. J., and P. Løvendahl. 2016. Heritability estimates for enteric methane emissions from Holstein cattle measured using noninvasive methods. J. Dairy Sci. 99:1959-1967. https://doi.org/10 .3168/jds.2015-10012.

Lassen, J., P. Løvendahl, and J. Madsen. 2012. Accuracy of noninvasive breath methane measurements using Fourier transform infrared methods on individual cows. J. Dairy Sci. 95:890-898. https:/ /doi.org/10.3168/jds.2011-4544.

Madsen, J., B. S. Bjerg, T. Hvelplund, M. R. Weisbjerg, and P. Lund. 2010. Methane and carbon dioxide ratio in excreted air for quantification of the methane production from ruminants. Livest. Sci. 129:223-227. https://doi.org/10.1016/j.livsci.2010.01.001.

Myhre, G., D. Shindell, F.-M. Bréon, W. Collins, J. Fuglestvedt, J. Huang, D. Koch, J.-F. Lamarque, D. Lee, B. Mendoza, T. Nakajima, A. Robock, G. Stephens, T. Takemura, and H. Zhan. 2013. Anthropogenic and natural radiative forcing. In Climate Change 2013: The Physical Science Basis. Contribution of Working Group I to the Fifth Assessment Report of the Intergovernmental Panel on Climate Change. https://www.ipcc.ch/report/ar5/wo1/.

Negussie, E., J. Lehtinen, P. Mäntysaari, A. R. Bayat, A.-E. Liinamo, E. A. Mäntysaari, and M. H. Lidauer. 2017. Non-invasive individual methane measurement in dairy cows. Animal 11:890-899. https://doi.org/10.1017/S1751731116002718.

van Engelen, S., H. Bovenhuis, P. P. J. van der Tol, and M. H. P. W. Visker. 2018. Genetic background of methane emissions by Dutch Holstein Friesian cows measured by infrared sensors in automatic milking system. J. Dairy Sci. 101:2226-2234. https://doi.org/10 .3168/jds.2017-13441.

Yan, T., F. J. Gordon, C. P. Ferris, R. E. Agnew, M. G. Porter, and D. C. Patterson. 1997. The fasting heat production and effect of lactation on energy utilisation by dairy cows offered forage-based diets. Livest. Prod. Sci. 52:177-186. https://doi.org/10.1016/S0301 -6226(97)00121-8.

Yan, T., C. S. Mayne, F. G. Gordon, M. G. Porter, R. E. Agnew, D. C. Patterson, C. P. Ferris, and D. J. Kilpatrick. 2010. Mitigation of enteric methane emissions through improving efficiency of energy utilization and productivity in lactating dairy cows. J. Dairy Sci. 93:2630-2638. https://doi.org/10.3168/jds.2009-2929.

\section{ORCIDS}

P. Huhtanen @ https://orcid.org/0000-0001-7855-7448

A. R. Bayat @ https://orcid.org/0000-0002-4894-0662

P. Lund (ㄷ https://orcid.org/0000-0002-9113-4500

A. L. F. Hellwing () https://orcid.org/0000-0002-2881-399X

M. R. Weisbjerg @ https://orcid.org/0000-0002-6514-9186 